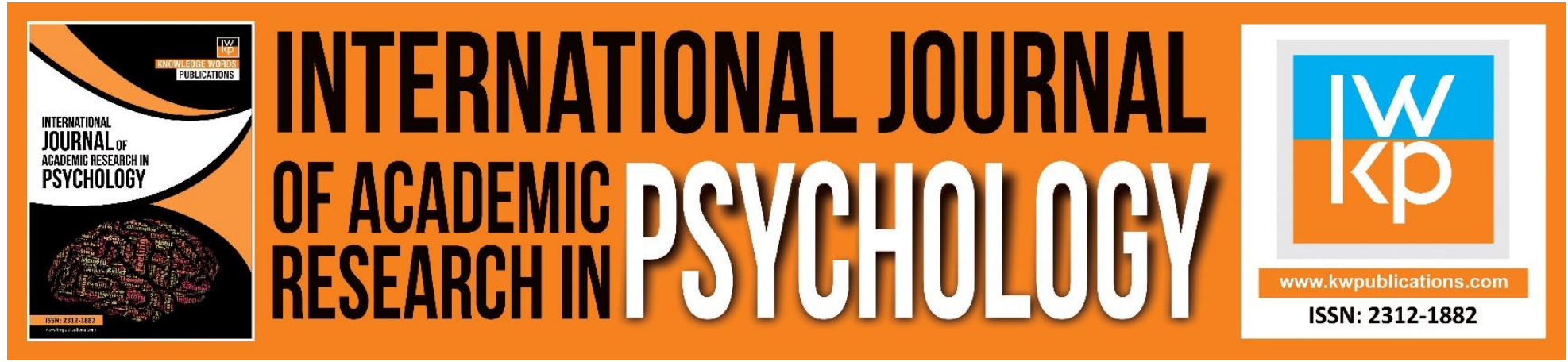

\title{
The Relationship between Students' Test Anxiety, Attachment Styles and Perfectionism
}

Masoud Hejazi, Vahideh Khalili

To Link this Article: http://dx.doi.org/10.46886/IJARP/v2-i1/1717

DOI: $10.46886 /$ IJARP/v2-i1/1717

Received: 18 April 2015, Revised: 21 May 2015, Accepted: 10 June 2015

Published Online: 24 June 2015

In-Text Citation: (Hejazi \& Khalili, 2015)

To Cite this Article: Hejazi, M., \& Khalili, V. (2015). The Relationship between Students' Test Anxiety, Attachment Styles and Perfectionism. International Journal of Academic Research in Psychology. 2(1), 2841.

Copyright: (c) 2015 The Author(s)

Published by Knowledge Words Publications (www.kwpublications.com)

This article is published under the Creative Commons Attribution (CC BY 4.0) license. Anyone may reproduce, distribute, translate and create derivative works of this article (for both commercial and non-commercial purposes), subject to full attribution to the original publication and authors. The full terms of this license may be seen at: http://creativecommons.org/licences/by/4.0/legalcode

Vol. 2, No. 1, 2015, Pg. 28 - 41

https://kwpublications.com/journals/journaldetail/IJARP

JOURNAL HOMEPAGE

Full Terms \& Conditions of access and use can be found at https://kwpublications.com/pages/detail/publication-ethics 


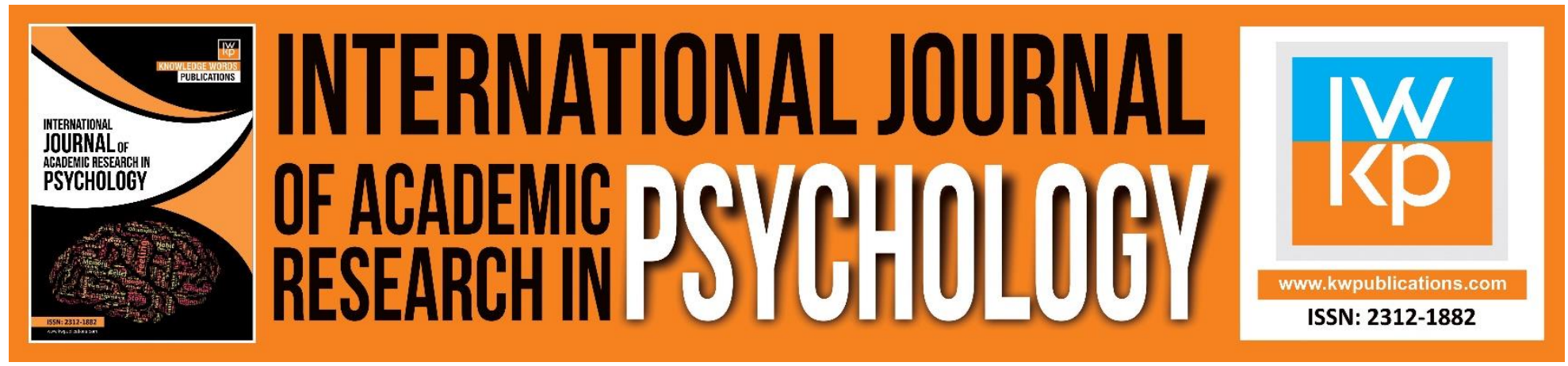

\title{
The Relationship between Students' Test Anxiety, Attachment Styles and Perfectionism
}

\author{
Masoud Hejazi, PhD, Vahideh Khalili \\ Department of Psychology, Zanjan Branch, Islamic Azad University, Zanjan, Iran
}

\begin{abstract}
Test anxiety is excessive worrying about test performance. When preparing for exams, a little sense of anxiety is perfectly normal. However, if it goes beyond the natural range, it may disrupt the performance of students during exam. It is because they will have a feeling of powerlessness in expressing and explaining their learning. Therefore, the study was aimed to investigate the relationship between students' test anxiety and attachment styles and perfectionism. For this purpose, 200 male and female third-grader high school students were selected by multistage cluster sampling method. The sample filled out Attachment Styles Questionnaire (Besharat, 2000), Frost's Perfectionism Questionnaire, and Sarason Test Anxiety Questionnaire individually. This study was based on correlation assumptions. Research criterion variable included test anxiety at one level, predictive variables included attachment at three levels of Secure Attachment, Ambivalent Attachment and Avoidant Attachment, and perfectionism at six levels as personal standards, organizing, concern on mistakes, doubting on actions, parental criticism and parental expectations.

The results of multiple regression analysis showed that ambivalent attachment pattern was a significant predictor of test anxiety and that, perfectionism played a significant role in test anxiety $(P<0 / 01)$. In addition, the results of variance analysis of the comparison of attachment patterns in male and female students showed that the level of ambivalent attachment in girls was higher than that of boys $(\mathrm{P}<0 / 05)$. The comparison of perfectionism and its related indicators showed that girls were more organized than boys $(\mathrm{P}<0 / 05)$. The comparison results of test anxiety between girls and boys indicated that there was no significant difference between the two groups. ambivalent attachment style was one of the Traumatic variables of students' test anxiety, which is accompanied with a feeling of insecurity and distresses the students. The perfectionism, as creator of rigid thought framework, was the important factor of this type of anxiety.
\end{abstract}

Keywords: Attachment Styles, Perfectionism, Test Anxiety.

\section{Introduction}

Anxiety may directly lead to poor performance, because the nature of evaluating conditions of the test disturbs concentration toward potential negative consequences. In this case, anxiety is not necessarily identical with physiological arousal. However, it may expose 
processes through which arousal or situational factors break the concentration on responses necessary for the task and divert it to negative cognitions during the test (Abolghasemi, 2003). Research findings confirm the effect of anxiety on performance, especially on the academic performance of students (Mousavi et al., 2008). test anxiety is among the various barriers to the use of knowledge, understandings, and previous information. Giada and Vouldlo (1989) defined test anxiety as an unpleasant emotional reaction to evaluation situations at schools or in classrooms. test anxiety is an unpleasant emotional condition accompanied with behavioral and physiological problems which is experienced in formal exams or other evaluative situations (Duske, 1980).

As an emotional consequence, test anxiety may root in attachment style and childhood attachment to parents. This may explain many behavioral and psychological states of the individuals throughout their academic and personal life. In general, the attachment styles determine the emotional and cognitive rules as well as the strategies which control emotional reactions of people in conflict situations and interpersonal relations (Shaver, Collins, and Clark, 1996). The results of Dunn et al. (2013) are indicative of a relationship between test anxiety dimensions and avoidant and ambivalent attachment styles of high school students and graduate students.

Perfectionism is another variable which may affect test anxiety. It is characterized by a person's striving for setting excessively high performance standards (Burns, 1980) accompanied by overly critical self-evaluations (Frost, Marten, Lahart and Rosenblate, 1990). Perfectionists strain toward unobtainable goals for people who are important for them (Felt et al., 1991). Therefore, perfectionism may lead to problematic interpersonal relations (Felt and Hooit, Blank Steen, 1998). Although these expectations are difficult to meet, these standards should be achieved by the person to be approved and accepted by the others (Frost et al., 1990; Hooit and Felt, 1991). According to various studies, there is relationship between perfectionistic feedbacks, especially those of self-oriented and community-oriented perfectionism, and anxiety and anxiety disorders (Antony et al., 1998; Juster et al., 1996; Frost \& steketee, 1997; Heimberg et al., 1995). Ram (2005) found that positive perfectionism is positively correlated with academic performance and negative Perfectionism has a significant negative correlation with academic performance. Therefore, it can be said that perfectionism has a relationship with test anxiety. In the research the outcomes of attachment styles and the affecting dimensions of perfectionism are studied using Bowlby's theory and Frost's theory (Frost, et al., 1990) respectively. In addition, as the two key variables of test anxiety, attachment styles and perfectionism have a significant correlation. In this regard, the results of the research showed that there is a significant relationship between attachment styles and positive and negative perfectionism; secure attachment style has a positive correlation with positive perfectionism and a negative correlation with negative perfectionism. Non-secure attachment styles (ambivalent and avoidant) have a negative correlation with positive perfectionism and a positive correlation with negative perfectionism (Basharet et al., 2011). Therefore, the main research question is: Is there a relationship between test anxiety and attachment styles and perfectionism?

\section{Method}

This was a correlation research. Statistic population included all male and female third-grader high school students enrolled in Zanjan in 1392-93 academic year [2013-14]. The minimum sample size required for structural equation modeling data was of great importance (Mc kitty, 
2004). Many researchers believe that the minimum sample size required is 200 people (Schreiber, 2006) though, there is not general agreement on the sample size required for factor analysis and structural models (haulter, 1983; Garver \& Montzer, 1999; Sive et al., 2006, Hu, 2008). Having this in mind, 10 schools (5 female schools: Shahid-fatimiyeh, Shahidzeynabiyeh, Parvin-e-Etesami, Hajar and Rughani Zanjani, and 5 male schools: Shahidpeyambar-e-azam, Shariati, Amirkabir, Saadat and Allameh Helli) were randomly selected out of 2 Education Areas of Zanjan City using multistage random sampling method. Then, 200 students were randomly selected out of these schools and, observing inclusion and exclusion criteria of the study, the questionnaires were distributed among them. Being explained by the researcher, the participants responded the questionnaires.

\section{Data Collection Instruments}

Field study was used for data collection purposes. The variables were assessed by questionnaires, which are explained in the section of data collection instruments.

\section{A) Adult Attachment Styles Questionnaire}

Attachment style of the subjects was determined by Adult Attachment Scale (Basharat, 2000). This scale was developed through using the materials of Hazan and Shaver attachment test (1987). It is a two-part questionnaire which was normalized on the students of Tehran University. At the first part, the three Attachment styles - Secure, Ambivalent and Avoidant - are distinguished through 21 questions in accordance with Likert 5 point scale (non=1, little $=2$, average $=3$, much $=4$, very much $=5$ ). Questions related to secure attachment style include $(1,3,5,7,11,12,14,19)$, to ambivalent attachment style $(2,6,9,10,16,17,21)$ and to avoidant attachment style $(4,8,13,15,18,20)$. The highest score in this section determines the general attachment style of the person. At the second part, participants describe their attachment style by choosing an option out of the three options describing three kinds of attachments. In the present research, the first part of the questionnaire was used to determine the general attachment style of the person.

Basharat (2000) used Cronbach's alpha and test-retest method to determine the reliability of the questionnaire. Cronbach's alpha coefficient for Secure, Avoidant, and Ambivalent Attachment styles concluded at $0.74,0.71$ and 0.69 respectively. In another study, Cronbach's alpha coefficient of the questionnaire in the general population was shown more than seventy percent. This coefficient represents a relatively satisfactory internal consistency. Content validity of the scale was evaluated by measuring the correlation between the scores of four psychologists, all of which was significant at 0.01(Besharet, 2000). Simultaneous implementation of this scale with Coopersmith Self-Esteem Inventory confirmed the validity of attachment styles questionnaire.

\section{B) Frost's Perfectionism Questionnaire}

Frost's Multidimensional Perfectionism is a 35 item questionnaire developed by Frost (1990) to measure perfectionism. The questionnaire includes 6 subscales as follows:

1) Concern over Mistakes: includes questions (9, 10, 13, 14, 18, 21, 23, 25, and 34). It is indicative of the negative reaction to mistakes, tendency to interpret mistakes as a failure (Equalizing mistakes with failure), and tendency to believe that failure (mistake) is followed by losing the respect and support of others. 
2) Parental expectations: The expectations of parents: believing that, parents or either of them has set high goals and standards for the person. It includes questions $(1,11,15,20$, and 26).

3) Parental criticism: includes questions (3, 5, 22, and 35). The person perceives that parents or one of them are/have been very critical.

4) Doubts about actions: consists of a few questions from the Maudsley's Compulsive Obsession Inventory and includes questions $(17,28,32$, and 33$)$.

5) Personal standards: includes questions $(4,6,12,16,19,24$, and 30). It represents that the person sets high standards and places excessive importance on these standards for selfevaluation purposes.

6) Organization: includes questions $(2,7,8,27,29$, and 31). This sub-scale evaluates the tendency of the person to be disciplined and organized. It is indicative of the person's emphasis on doing things in order, which is correlated with perfectionism.

The questions measure subjects' perfectionism rated from 1 to 5 based on Likert 5 point scale (strongly disagree, disagree, neutral, agree, and strongly agree). Using factor analysis, Frost Himberg et al (1993) in their study on perfectionism scale determined that the scale is both positive and negative, that is, negative perfectionism can be concluded by the four subscales of Concern Over Mistakes, Parental Expectations, Parental Criticism, and Doubts About Actions and positive perfectionism can be concluded by the two subscales of Personal Standards and Organization.

Validity of the scale in the study of Frost et al. (1990) has been reported as general perfectionism 90\%, Concern over Mistakes 88\%, Parental Expectations 84\%, Parental Criticism 84\%, Doubts about Actions 77\%, Personal Standards $83 \%$ and Organization $93 \%$. This questionnaire is highly correlated with other perfectionism scales particularly with those of Burns Perfectionism Scale (Burns, 1980), self-assessment scale (Juter, 1968), and Perfectionism Scale of Garner et al. (1983) (Frost et al., 1993). The study conducted by Frost et al. (1993) also showed that perfectionism assessment instruments formed on the basis of a different conceptualization by Frost et al. (1990) and Flett \& Hewitt are highly correlated.

C) Test Anxiety Inventory: the Sarason's Test Anxiety Scale was used for measuring test anxiety level. This scale consists of 25 items responded by the subjects based on a multiple choice inventory $(0=$ never, $1=$ rarely, $2=$ sometimes, $3=$ often $)$. The test has a minimum score of zero and a maximum of 75 . Higher scores indicate more anxiety.

In a sample of students, Cronbach's alpha coefficient of test anxiety questions was calculated as 0.94 for the total sample, 0.95 for female participants and 0.92 for male subjects, indicating high internal consistency of the scale. Correlation coefficients of the scores of the subjects were calculated twice with an interval of four to six weeks at $r=0 / 77$ for the total sample, $r=0 / 88$ for female subjects and $r=0 / 67$ for male subjects, which is indicative of satisfactory reliability of the scale (Besharet, 2004). Humand (1995) reported the scale validity at 0.84 by split-half method. Significant correlation of the scale with improvement and intelligence is indicative of its construct validity. Convergent validity coefficient between this scale and school anxiety questionnaire was reported at 0.84 (Phillips, 1996).

In the present study, Cronbach's alpha was used to determine the reliability of the questionnaires of attachment styles, perfectionism, and test anxiety. 


\begin{tabular}{lcc}
\hline \multicolumn{1}{c}{ Table 1: The results of internal consistency of research instruments } \\
\hline \multicolumn{1}{c}{ variable } & Number of questions & Cronbach's alpha \\
$\begin{array}{l}\text { Concern over } \\
\text { Mistakes }\end{array}$ & 9 & 0.79 \\
Parental Expectations & 5 & 0.59 \\
Parental Criticism & 4 & 0.65 \\
Doubts About Actions & 4 & 0.62 \\
Personal Standards & 7 & 0.61 \\
Organization & 6 & 0.81 \\
Perfectionism & 35 & 0.79 \\
Secure attachment & 7 & 0.72 \\
Avoidant attachment & 7 & 0.63 \\
Ambivalent & 7 & 0.65 \\
attachment & & \\
Test Anxiety & 25 & 0.78 \\
\hline
\end{tabular}

The results of internal consistency of the data collection instruments in this study are presented in Table 1. Using Cronbach's alpha, internal consistency of the variables was calculated at 0.59 to 0.81 . This implies that the instruments used in this study had good internal consistency.

\section{Findings}

Statistical analysis done in this section includes descriptive analysis and inferential analysis.

\section{Descriptive Statistical Analysis}

In the section, after data collection, the sample was described using descriptive statistics which involves Central Index, mean, Distribution and standard deviation.

\begin{tabular}{|c|c|c|c|c|c|}
\hline Variable & Count & Mean & Standard deviation & Lowest & Highest \\
\hline $\begin{array}{l}\text { Concern over } \\
\text { Mistakes }\end{array}$ & 200 & $27 / 10$ & $6 / 80$ & 11 & 45 \\
\hline Parental Expectations & 200 & $16 / 85$ & $3 / 59$ & 5 & 25 \\
\hline Parental Criticism & 200 & $10 / 17$ & $3 / 14$ & 4 & 18 \\
\hline Doubts About Actions & 200 & $11 / 94$ & $4 / 68$ & 3 & 63 \\
\hline Personal Standards & 200 & $24 / 29$ & $4 / 29$ & 10 & 35 \\
\hline Organization & 200 & $21 / 77$ & $4 / 78$ & 7 & 30 \\
\hline Perfectionism & 200 & $112 / 11$ & $16 / 34$ & 78 & 194 \\
\hline Secure attachment & 200 & $19 / 08$ & $3 / 11$ & 10 & 28 \\
\hline Avoidant attachment & 200 & $18 / 06$ & $3 / 457$ & 11 & 30 \\
\hline $\begin{array}{l}\text { Ambivalent } \\
\text { attachment }\end{array}$ & 200 & 1798 & $5 / 19$ & 8 & 31 \\
\hline Test Anxiety & 200 & $64 / 49$ & $11 / 92$ & 32 & 110 \\
\hline
\end{tabular}

According to the results of Table 2, among the components of perfectionism, concern over mistakes had the highest mean 27.10 and parental criticism had the lowest mean 10.17. The mean of secure attachment, avoidant attachment, and ambivalent attachment was 
$19.08,18.06$, and 17.98 , respectively and the mean of test anxiety level was achieved at 64.49 .

\section{Inferential Statistics and Hypothesis Testing}

Data normalization using Kolmogorov-Smirnov test:

In order to use statistical techniques, normal or abnormal distribution of the collected data must be determined. It is because, in normal distribution, the parametric tests may be used to test hypotheses. In case of abnormal distribution, the nonparametric tests will be used. At this stage, we study the results of the test for dependent and independent variables and choose suitable test for the study of the hypotheses based on the results.

Table 3: Normality of dependent and independent variables

\begin{tabular}{|c|c|c|c|c|}
\hline Variable & $\begin{array}{l}\text { Kolmogorov- } \\
\text { Smirnov }\end{array}$ & p-value (sig) & $\begin{array}{l}\text { Confirmed } \\
\text { hypothesis }\end{array}$ & Conclusion \\
\hline $\begin{array}{l}\text { Concern over } \\
\text { Mistakes }\end{array}$ & $1 / 02$ & $0 / 28$ & $\mathrm{HO}$ & Normal \\
\hline $\begin{array}{l}\text { Parental } \\
\text { Expectations }\end{array}$ & $1 / 10$ & $0 / 17$ & $\mathrm{HO}$ & Normal \\
\hline Parental Criticism & $1 / 22$ & $0 / 13$ & $\mathrm{HO}$ & Normal \\
\hline $\begin{array}{l}\text { Doubts About } \\
\text { Actions }\end{array}$ & $1 / 96$ & $0 / 25$ & $\mathrm{HO}$ & Normal \\
\hline $\begin{array}{l}\text { Personal } \\
\text { Standards }\end{array}$ & $1 / 12$ & $0 / 16$ & $\mathrm{HO}$ & Normal \\
\hline Organization & $1 / 05$ & $0 / 22$ & $\mathrm{HO}$ & Normal \\
\hline Perfectionism & $0 / 98$ & $0 / 29$ & $\mathrm{HO}$ & Normal \\
\hline Secure attachment & $1 / 04$ & $0 / 23$ & $\mathrm{HO}$ & Normal \\
\hline $\begin{array}{l}\text { Avoidant } \\
\text { attachment }\end{array}$ & $1 / 18$ & $0 / 12$ & $\mathrm{HO}$ & Normal \\
\hline $\begin{array}{l}\text { Ambivalent } \\
\text { attachment }\end{array}$ & $1 / 04$ & $0 / 23$ & $\mathrm{HO}$ & Normal \\
\hline Test Anxiety & $0 / 92$ & $0 / 36$ & $\mathrm{HO}$ & Normal \\
\hline
\end{tabular}

The results of normality of variables are presented in Table 3. Considering the results of the table, all variables are normal at $\alpha=0.05$. For all of them, the $p$-value is greater than 0.05 . According to the results of following table, if the significance level will be greater than error value, the null hypothesis will be concluded. If significance level will be smaller than error value, hypothesis one will be concluded.

It is worth noting that, depending on the scale type and the normality of the population, the Pearson correlation coefficient was used for the relationship between the variables.

\section{Testing Research Hypotheses}

I. The main hypothesis of the study: There is relationship between students' test anxiety and attachment styles and perfectionism. 


\begin{tabular}{|c|c|c|c|c|c|c|c|c|c|c|c|}
\hline variables & (1) & (2) & (3) & (4) & (5) & (6) & (7) & (8) & (9) & $(1$ & $(1$ \\
\hline \multirow{2}{*}{$\begin{array}{l}\text { (1)Conce } \\
\text { rn over } \\
\text { Mistakes }\end{array}$} & 1 & & & & & & & & & & \\
\hline & & & & & & & & & & & \\
\hline \multirow{2}{*}{$\begin{array}{l}\text { (2)Parent } \\
\text { al } \\
\text { Expectati } \\
\text { ons }\end{array}$} & $\begin{array}{l}0.471 \\
* *\end{array}$ & 1 & & & & & & & & & \\
\hline & 0.001 & & & & & & & & & & \\
\hline \multirow[t]{2}{*}{$\begin{array}{l}\text { (3)Parent } \\
\text { al } \\
\text { Criticism }\end{array}$} & $\begin{array}{l}0.356 \\
* *\end{array}$ & $\begin{array}{l}0.3 \\
25^{*} \\
*\end{array}$ & 1 & & & & & & & & \\
\hline & 0.001 & $\begin{array}{l}0.0 \\
01\end{array}$ & & & & & & & & & \\
\hline \multirow{3}{*}{$\begin{array}{l}\text { (4)Doubt } \\
\text { s About } \\
\text { Actions }\end{array}$} & 0.473 & 0.2 & 0.2 & 1 & & & & & & & \\
\hline & & $\begin{array}{l}98 * \\
*\end{array}$ & $\begin{array}{l}31^{*} \\
*\end{array}$ & & & & & & & & \\
\hline & 0.001 & $\begin{array}{l}0.0 \\
01\end{array}$ & $\begin{array}{l}0.0 \\
01\end{array}$ & & & & & & & & \\
\hline \multirow{2}{*}{$\begin{array}{l}\text { (5)Person } \\
\text { al } \\
\text { Standard } \\
\text { s }\end{array}$} & $\begin{array}{l}0.288 \\
* *\end{array}$ & $\begin{array}{l}0.3 \\
64^{*} \\
*\end{array}$ & $\begin{array}{l}- \\
0.0 \\
79\end{array}$ & $\begin{array}{l}0.1 \\
67 *\end{array}$ & 1 & & & & & & \\
\hline & 0.001 & $\begin{array}{l}0.0 \\
01\end{array}$ & $\begin{array}{l}0.2 \\
65\end{array}$ & $\begin{array}{l}0.0 \\
18\end{array}$ & & & & & & & \\
\hline \multirow[t]{2}{*}{$\begin{array}{l}\text { (6)Organi } \\
\text { zation }\end{array}$} & 0.049 & $\begin{array}{l}0.0 \\
10\end{array}$ & $\begin{array}{l}- \\
0.1 \\
85^{*} \\
*\end{array}$ & $\begin{array}{l}0.0 \\
13\end{array}$ & $\begin{array}{l}0.2 \\
76^{*} \\
*\end{array}$ & 1 & & & & & \\
\hline & 0.493 & $\begin{array}{l}0.8 \\
84\end{array}$ & $\begin{array}{l}0.0 \\
39\end{array}$ & $\begin{array}{l}0.8 \\
53\end{array}$ & $\begin{array}{l}0.0 \\
01\end{array}$ & & & & & & \\
\hline \multirow[t]{2}{*}{$\begin{array}{l}\text { (7)Perfec } \\
\text { tionism }\end{array}$} & $\begin{array}{l}0.813 \\
* *\end{array}$ & $\begin{array}{l}0.6 \\
62 * \\
*\end{array}$ & $\begin{array}{l}0.4 \\
03 * \\
*\end{array}$ & $\begin{array}{l}0.6 \\
41 * \\
*\end{array}$ & $\begin{array}{l}0.5 \\
76^{*} \\
*\end{array}$ & $\begin{array}{l}0.3 \\
56^{*} \\
*\end{array}$ & 1 & & & & \\
\hline & 0.001 & $\begin{array}{l}0.0 \\
01\end{array}$ & $\begin{array}{l}0.0 \\
01\end{array}$ & $\begin{array}{l}0.0 \\
01\end{array}$ & $\begin{array}{l}0.0 \\
01\end{array}$ & $\begin{array}{l}0.0 \\
31\end{array}$ & & & & & \\
\hline \multirow[t]{2}{*}{$\begin{array}{l}\text { (8)Secure } \\
\text { attachme } \\
\text { nt }\end{array}$} & 0.041 & $\begin{array}{l}0.0 \\
98\end{array}$ & $\begin{array}{l}- \\
0.0 \\
19\end{array}$ & $\begin{array}{l}- \\
0.0 \\
40\end{array}$ & $\begin{array}{l}0.0 \\
18\end{array}$ & $\begin{array}{l}- \\
0.0 \\
42\end{array}$ & $\begin{array}{l}0.0 \\
16\end{array}$ & 1 & & & \\
\hline & 0.561 & $\begin{array}{l}0.1 \\
66 * \\
*\end{array}$ & $\begin{array}{l}0.7 \\
93^{*} \\
*\end{array}$ & $\begin{array}{l}0.5 \\
78^{*} \\
*\end{array}$ & $\begin{array}{l}0.8 \\
03\end{array}$ & $\begin{array}{l}0.5 \\
58\end{array}$ & $\begin{array}{l}0.8 \\
17\end{array}$ & & & & \\
\hline $\begin{array}{l}\text { (9)Avoida } \\
\text { nt }\end{array}$ & $\begin{array}{l}0.147 \\
*\end{array}$ & $\begin{array}{l}0.0 \\
61\end{array}$ & $\begin{array}{l}0.2 \\
14 * \\
*\end{array}$ & $\begin{array}{l}0.1 \\
34\end{array}$ & $\begin{array}{l}0.1 \\
89 * \\
*\end{array}$ & $\begin{array}{l}0.0 \\
84\end{array}$ & $\begin{array}{l}0.2 \\
28 * \\
*\end{array}$ & $\begin{array}{l}- \\
0.24 \\
1 * *\end{array}$ & 1 & & \\
\hline
\end{tabular}




\begin{tabular}{|c|c|c|c|c|c|c|c|c|c|c|c|}
\hline $\begin{array}{l}\text { attachme } \\
\text { nt }\end{array}$ & 0.037 & $\begin{array}{l}0.3 \\
90 * \\
*\end{array}$ & $\begin{array}{l}0.0 \\
02\end{array}$ & $\begin{array}{l}0.0 \\
58\end{array}$ & $\begin{array}{l}0.0 \\
07\end{array}$ & $\begin{array}{l}0.2 \\
40\end{array}$ & $\begin{array}{l}0.0 \\
11\end{array}$ & $\begin{array}{l}0.02 \\
1\end{array}$ & & & \\
\hline \multirow{2}{*}{$\begin{array}{l}\text { (10)Ambi } \\
\text { valent } \\
\text { attachme } \\
\text { nt }\end{array}$} & $\begin{array}{l}0.353 \\
* *\end{array}$ & $\begin{array}{l}0.1 \\
54^{*}\end{array}$ & $\begin{array}{l}0.2 \\
27^{*} \\
*\end{array}$ & $\begin{array}{l}0.1 \\
84^{*} \\
*\end{array}$ & $\begin{array}{l}0.0 \\
58\end{array}$ & $\begin{array}{l}- \\
0.0 \\
41\end{array}$ & $\begin{array}{l}0.2 \\
80 * \\
*\end{array}$ & $\begin{array}{l}0.01 \\
0\end{array}$ & $\begin{array}{l}0.3 \\
44^{*} \\
*\end{array}$ & 1 & \\
\hline & 0.001 & $\begin{array}{l}0.0 \\
30\end{array}$ & $\begin{array}{l}0.0 \\
01\end{array}$ & $\begin{array}{l}0.0 \\
09\end{array}$ & $\begin{array}{l}0.4 \\
17^{*} \\
*\end{array}$ & $\begin{array}{l}0.5 \\
62 * \\
*\end{array}$ & $\begin{array}{l}0.0 \\
01\end{array}$ & $\begin{array}{l}0.88 \\
6\end{array}$ & $\begin{array}{l}0.0 \\
11\end{array}$ & & \\
\hline \multirow[t]{2}{*}{$\begin{array}{l}\text { (11)Test } \\
\text { Anxiety }\end{array}$} & $\begin{array}{l}0.446 \\
* *\end{array}$ & $\begin{array}{l}0.3 \\
57^{*} \\
*\end{array}$ & $\begin{array}{l}0.3 \\
60 * \\
*\end{array}$ & $\begin{array}{l}0.4 \\
73^{*} \\
*\end{array}$ & $\begin{array}{l}0.1 \\
01\end{array}$ & $\begin{array}{l}0.0 \\
04\end{array}$ & $\begin{array}{l}0.5 \\
10 * \\
*\end{array}$ & $\begin{array}{l}- \\
0.09 \\
4\end{array}$ & $\begin{array}{l}0.2 \\
07 * \\
*\end{array}$ & $\begin{array}{l}0.3 \\
55 \\
* *\end{array}$ & 1 \\
\hline & 0.001 & $\begin{array}{l}0.0 \\
01\end{array}$ & $\begin{array}{l}0.0 \\
01\end{array}$ & $\begin{array}{l}0.0 \\
01\end{array}$ & $\begin{array}{l}0.0 \\
65\end{array}$ & $\begin{array}{l}0.7 \\
35\end{array}$ & $\begin{array}{l}0.0 \\
11\end{array}$ & $\begin{array}{l}0.18 \\
6\end{array}$ & $\begin{array}{l}0.0 \\
03\end{array}$ & $\begin{array}{l}0.0 \\
01\end{array}$ & \\
\hline
\end{tabular}

$* * p<0.01 \quad * p<0.05$

The results of correlation showed that there is significant and positive correlation between test anxiety and avoidant and ambivalent attachment styles (0.001). Also, there is positive and significant correlation between test anxiety and perfectionism (0.001). The relationship between test anxiety and perfectionism subscales (including concern over mistakes, parental expectations, parental criticism, and doubts) was significant and positive (0.001). Although there was a positive correlation between test anxiety and perfectionism sub-scales, such as personal standards and organization, it was not significant.

The linear regression was used to study separately the relationship and the role of each independent variable with test anxiety.

Table 5: Adequacy of models of relationship between test anxiety and attachment styles

\begin{tabular}{|r|r|r|r|r|}
\hline Correlation coefficient & $\begin{array}{r}\text { Coefficient of } \\
\text { determination }\end{array}$ & $\begin{array}{r}\text { Adjusted Coefficient } \\
\text { of determination }\end{array}$ & $\begin{array}{r}\text { SD } \\
\text { error }\end{array}$ & $\begin{array}{r}\text { Dooorbin - } \\
\text { Vastoun }\end{array}$ \\
\hline $0 / 374$ & 0.140 & $0 / 127$ & $11 / 13$ & $1 / 865$ \\
\hline
\end{tabular}

The correlation between independent variables and dependent variables is equal to 0.374 . The coefficient of determination was obtained at 0.140 . This value indicates that $14 \%$ of variation in test anxiety is associated with attachment styles. Since the statistic value of Doorbin-Watson is greater than standard value of 1.5 , it is concluded that the remaining values are independent. Based on the mentioned criteria, the model has efficiency.

The following table shows the significance of regression calculated by Fisher's $F$ test. 
INTERNATIONAL JOURNAL OF ACADEMIC RESEARCH IN PSYCHOLOGY Vol. 2, No. 1, 2015, E-ISSN: 2312-1882 ๔ 2015 KWP

\begin{tabular}{|r|r|r|r|r|r|}
\hline \multicolumn{6}{|c|}{ Table 6: Fisher F test, the significance of the regression in relationship between } \\
attachment styles and test anxiety \\
\hline Model & sum of squares & sree of freedom & an of square & F statistic & Sig. \\
\hline Regression & $3951 / 768$ & 3 & $1317 / 256$ & $10 / 622$ & $0 / 001$ \\
\hline Residual & $24307 / 130$ & 196 & $124 / 016$ & & \\
\hline Total & $28258 / 898$ & 199 & & & \\
\hline
\end{tabular}

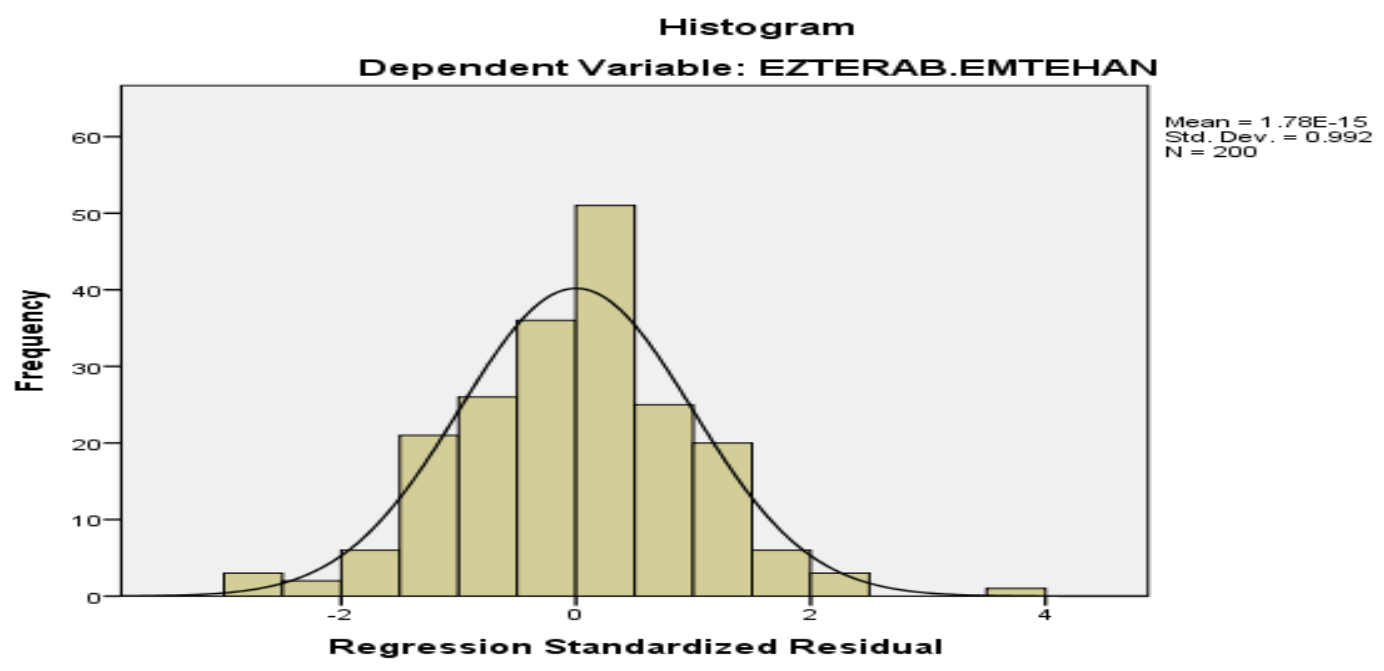

Figure (1): the relationship between attachment styles and test anxiety based on F test

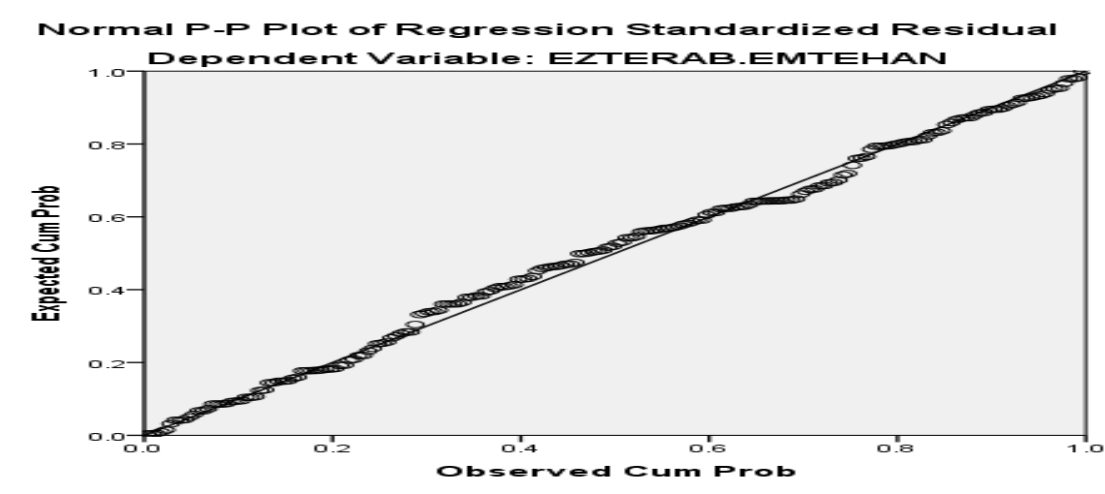

Figure (2) Normality of the residuals

\begin{tabular}{|r|r|r|r|r|r|}
\hline \multicolumn{7}{|c|}{ Table 7: Regression coefficients of attachment styles and test anxiety } \\
\hline Model & Non-standard coefficient & Standard coefficient & t & \multirow{2}{*}{ Sig. } \\
\cline { 2 - 5 } & $\mathrm{B}$ & Std. Error & Beta & & \\
\hline (constant value) & $52 / 045$ & $7 / 372$ & & $7 / 060$ & $0 / 001$ \\
\hline Secure attachment & $-0 / 304$ & $0 / 263$ & $-0 / 079$ & $-1 / 158$ & $0 / 248$ \\
\hline Avoidant attachment & $0 / 255$ & $0 / 252$ & $0 / 074$ & $1 / 012$ & $0 / 313$ \\
\hline Ambivalent attachment & $0 / 758$ & $0 / 163$ & $0 / 330$ & $4 / 655$ & $0 / 001$ \\
\hline
\end{tabular}


According to Table 7, the results of Multiple Regression Test Analysis shows that standardized beta coefficient gives a measure to assess the share of each variable in the model. The $p$ and $t$ values refer to the effect of each predictor variables. The $t$ and $p$ values show that there is significant relationship between predictor and criterion variables. Accordingly, ambivalent attachment style is a significant predictor for test anxiety $(\beta=0.330)$. The Beta's positive sign indicates that test anxiety can be seen significantly more in people with ambivalent attachment.

II. There is relationship between perfectionism and test anxiety of students.

Table 8: The adequacy index of model of relationship between test anxiety and perfectionism

\begin{tabular}{|r|r|r|r|r|}
\hline Dooorbin - Vastoun & SD error & $\begin{array}{r}\text { Adjusted Coefficient of } \\
\text { determination }\end{array}$ & $\begin{array}{r}\text { Coefficient of } \\
\text { determination }\end{array}$ & Correlation \\
\hline $1 / 760$ & $10 / 27779$ & $0 / 256$ & $0 / 260$ & $0 / 510$ \\
\hline
\end{tabular}

Table 9. F-test on the significance of the regression of the relationship between perfectionism and test-anxiety

\begin{tabular}{|l|l|l|l|l|l|l|}
\hline Model & \multicolumn{2}{|l|}{ Sum of squares } & $\begin{array}{l}\text { Degree of } \\
\text { freedom }\end{array}$ & $\begin{array}{l}\text { Mean- } \\
\text { square }\end{array}$ & F-statistic & Sig. \\
\hline Regression & 7343.552 & 1 & 7343.552 & 69.519 & 0.001 \\
\hline Residual & 20915.346 & 198 & 105.633 & & \\
\hline Total & 28258.898 & 199 & & & \\
\hline
\end{tabular}

The results in Table 9 show that $P<0.001$. As a result, the entire model is significant.

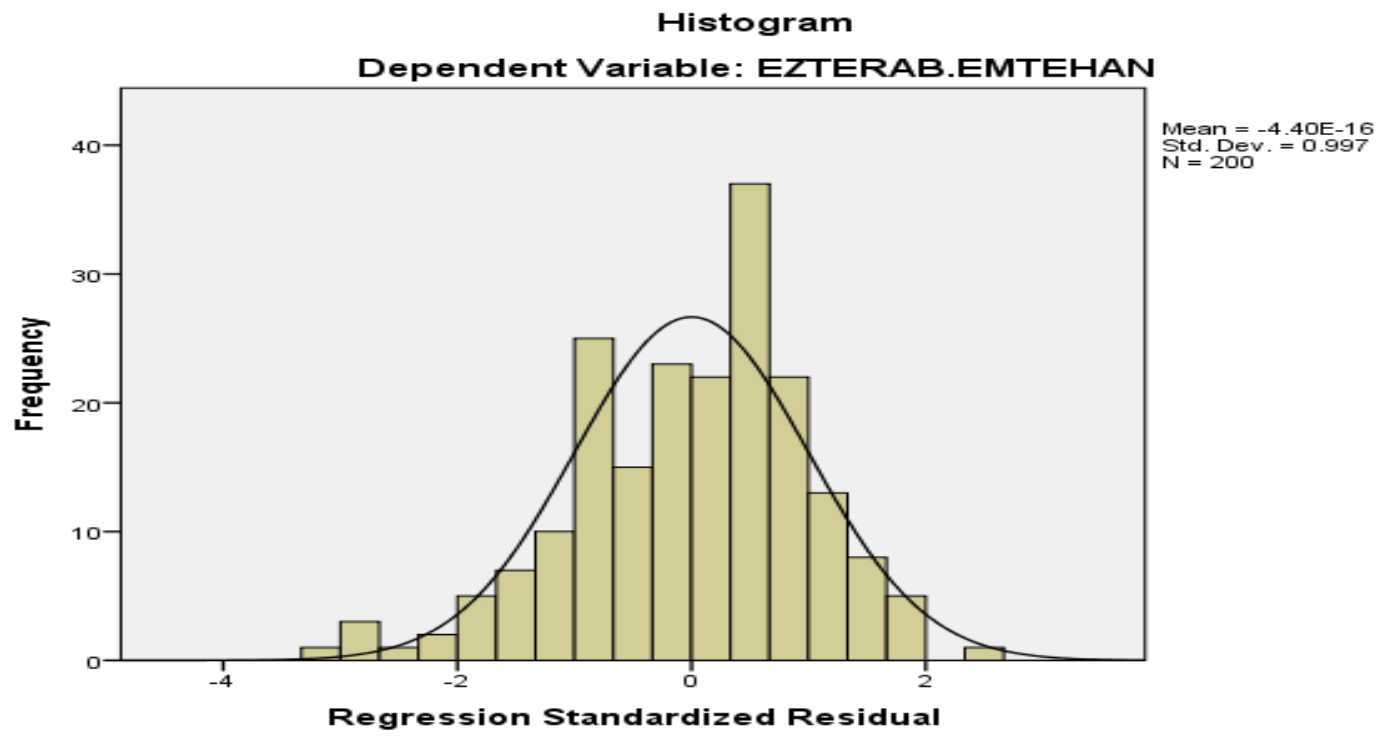

Figure (3): the relationship between perfectionism and test anxiety based on F test 


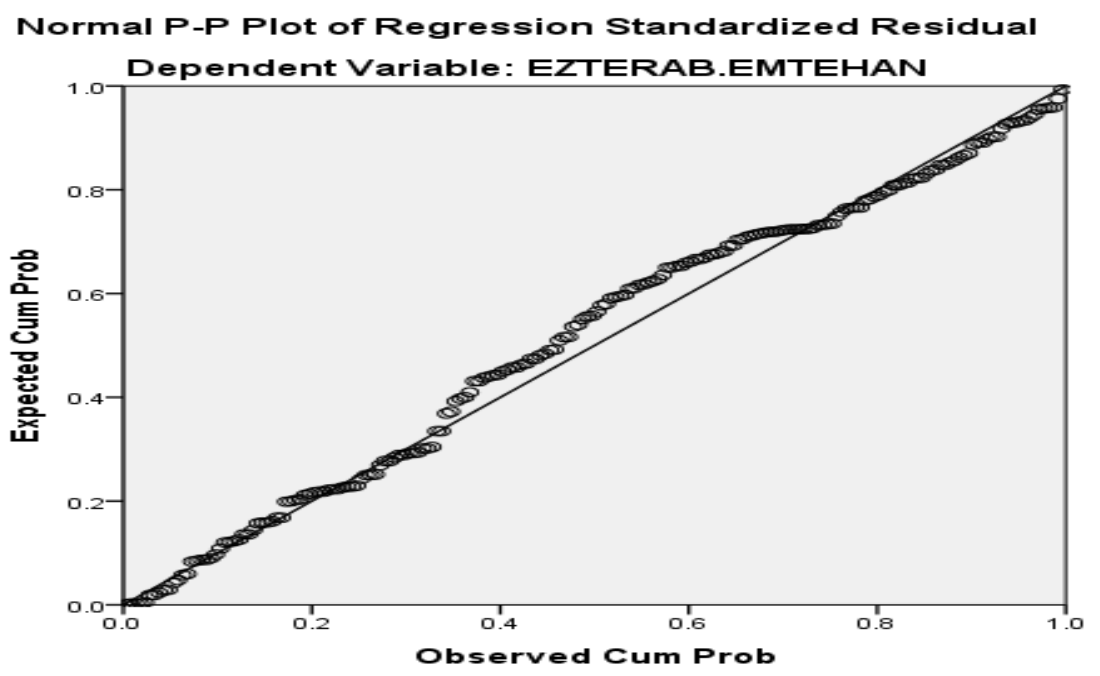

Figure (4): the normality of residuals

Table 10. Regression coefficient of the relationship between perfectionism and test anxiety

\begin{tabular}{|r|r|r|r|r|r|}
\hline & \multirow{2}{*}{ Significance level } & & \multicolumn{2}{|l|}{$\begin{array}{c}\text { Standard } \\
\text { coefficients }\end{array}$} & \multicolumn{2}{|l|}{ Mon-standardized coefficients } \\
\cline { 3 - 6 } & & Beta & Std .Error & B & constant value \\
\hline $0 / 01$ & $4 / 515$ & & $5 / 051$ & $22 / 803$ & Perfectionism \\
\hline $0 / 01$ & $8 / 338$ & $0 / 510$ & $0 / 045$ & $0 / 372$ & \\
\hline
\end{tabular}

According to Table 10, the results of Multiple Regression Test Analysis show that standardized beta coefficient gives a measure to assess the share of each variable in the model. The $p$ and $t$ values refer to the effect of predictor variable. The $t$ and $p$ values show that there is significant relationship between predictor and criterion variables. Accordingly, perfectionism is a significant predictor for test anxiety $(\beta=0.510)$. The Beta's positive sign indicates that test anxiety can be seen significantly more in people with perfectionism.

\section{Discussion and Conclusion}

After reviewing and considering parametric test assumptions in this study, Pearson correlation and multiple regression tests were used to evaluate the correlation between predictor and criterion variables. The results of correlation between test anxiety and attachment styles showed that there is significant and positive correlation between test anxiety and avoidant and ambivalent attachment styles (0.001). Although there was a negative correlation between test anxiety and secure attachment, it was not significant. The results of determination coefficient in regression also showed that 14 percent of variation in test anxiety is associated with attachment styles. The standardized beta coefficient also showed that ambivalent attachment style is a significant predictor for test anxiety. This means that test anxiety can be seen significantly more in people with ambivalent attachment. These results are consistent with those of Öztürk (2010); Bifulcoet al. (2006); Morris et al. (2001). Mutlu and Ozturk (2010) found that students with frightened and distressed attachment styles experience higher levels of social anxiety than students with secure attachment style. The results of Bifulco et al (2006) suggest that non-secure attachment style explains significantly anxiety and depression in the studied women. 
In a study on the relationship between attachment styles and symptoms of anxiety and depression in adolescents, Morris et al. (2001) showed that the teens with secure attachment style had significantly lower anxiety and depression than those with non-secure attachment (avoidant and ambivalent) styles. Regarding the relationship between avoidant and ambivalent attachment styles and test anxiety, it can be explained that excitement is the central point of the attachments. The excitements such as anxiety are strategies and extreme states of avoidant and ambivalent attachment styles.

The results of Pearson correlation between test anxiety and perfectionism and its indicators showed that there is significant and positive correlation between them $(p<0.001)$. The correlation between test anxiety and concern over mistakes, parental expectations, parental criticism, and doubts sub-scales was significant and positive $(p<0.001)$. These results are consistent with those of Ghadami (2014); Egan (2008); Habkeh and Flynn (2002); and Kuuy and Mac Inner (2007). In this research, the results showed that dimensions of perfectionism affect test anxiety in students. Based on these results, it can be explained that perfectionism increases the unrealistic expectations of students and their critical evaluation of themselves. Perfectionism leads to the imposition of measures such as ideal measures to achieve results. The process of imposing perfectionism standards on students and their non-alignment with their capabilities increases the fear of failure and avoidant behaviors. Clearly, this contributes to students' test anxiety. By internalizing perfectionism, particularly in academic field, the unrealistic expectations and inflexible aspirations from student will increase. In this case, the individuals not only cannot experience the success, they also experience anxiety and fear of failure such as poor grades. This lack of personal satisfaction due to perfectionism has important contribution to students' test anxiety.

\section{References}

Basharat, M. A., Jooshanlou, M., Mirzamanai, S. M. (2011). The relationship between attachment styles and perfectionism. Bimonthly Journal of Behavior, Vol XIV, No. 25.

Basharat, M. A. (2004). The relationship between test anxiety of students and perfectionism of parents. Psychology and Education, Tehran University in 2004 (68).

Bifulco, A., Kwon, J., Jacobs, C., Moran, P., Bunn, A., \& Beer, N. (2006). Adult attachment style as mediator between childhood neglect/abuse and adult depression and anxiety. Social Psychiatry and Psychiatric Epidemiology October 2006, Volume 41, Issue 10, pp 796-805

Burns, D. (1980). The perfectionist's script for selfdefeat. Psychology Today, November, 3451.

Dan, O., Bar, I., Kurman, J. (2013). Attachment, self-esteem and test anxiety in adolescence and early adulthood. Educational Psychology: An International Journal of Experimental Educational Psychology. DOI:10.1080/01443410.2013.814191.

Flett, G. L., Hewitt, P. L., \& Singer, A. (1995). Perfectionism and parental authority styles. IndividualPsychology, 51 (1), 50-60.

Flett, G. L., Hewitt, P. L., Blankstein, K. R., \& O’Brien, S. (1991). Perfectionism and learned resourcefulnessin depression and self-esteem. Personalityand Individual Differences, 12, 61-68.

Frost, R. O., Marten, P., Lahart, C., \& Rosenblate, R. (1990). The dimensions of perfectionism.Cognitive Therapy and Research, 14, 449-468. 
Hazan, C., \& Shaver, P. (1998). Attachment as an organizational frameworkfor research on close relationships. Psychological Inquiry, 5, 1-22.

Mousavi, H. H., Shahi, A. M. J., Najmi, S. B. (2008). Test anxiety and a number of individualsocial factors associated with it in high school students in Shiraz. Behavioral Science Research. 11. 17-25.

Muris, P., Corvan, M., \& Marion, Z. L. (2001). Self-reported attachment style, attachment quality, and symptoms of anxiety and depression in young adolescents. Personality and Individual Differences. Volume 30, Issue 5, Pages 809-818.

Schreiber, J. B., Nora, A., Stage, F. K., Barlow, E. A., King, J. (2006). Reporting Structural Equation Modeling and Confirmatory Factor Analysis Results: A Review. Journal of Educational Research. 99(6), 323-337. 